\title{
GAUGING THE EFFECT OF JOB ENRICHMENT ON EMPLOYEE PERFORMANCE WITH THE MEDIATING ROLE OF EMPLOYEE MOTIVATION: EVIDENCE FROM PRIVATE BANKING SECTOR OF PAKISTAN
}

\author{
Ayesha Haroon and Tajjali Shakil
}

\begin{abstract}
The purpose of the study is to classify the effect of job enrichment on employee performance. Job enrichment has a fundamental tool of employee motivation for enhancing the performance of employee. The main objective is to motivate the employee by gauging the job enrichment effects on employee performance thus focuses on effect of job enrichment on job performance through motivation on employee performance. The study uses quantitative approach and use descriptive as well as inferential analysis through SPSS \& SMART PLS.
\end{abstract}

Keywords: Task Identity, Task Significance, Employee Motivation, Employee Performance

\section{INTRODUCTION}

Tasks are given to all employees that and that must be performed in a small pieces or parts (Slocum \& Sims, 2000). Job enrichment is a technique declared by (Kotila, 2001) that will be used to encourage the employees for their work and to let them perform high quality work for their job (Mione, 2004). Job enrichment includes providing such a management system to employees that will help them to develop their own skills and learn some from their employers and let them free to make their own dimensions for their selves (except the rights of its director). The Physical condition of a job is just to increase the satisfaction level of an employee who takes the responsibility to done the work on time (Raza \& Nawaz, 2011).

The world has made many changes and challenging the multinational and local companies in order to control the production cost which is increasing every day after. The mostly seen problem of a job enrichment now a days is on the corporate platform every organization is looking forward to increase their clientage in the whole world they are ready to turn there selves towards the aggressive competition held by world in the middle called quest. Raza and Nawaz (2011); Mohsan Nawaz Khan Shaukat and Aslam (2011); Dost and Khan (2012). In fact according to Dost and Khan (2012) as long as we give the flexibility to the employee there 
work performance and efficiency will increase gradually and every person will be giving their best to their work. Supported by Garg and Rastogi (2006), design of a job must increase the control and variety of skills fosters creativity proportion, constancy of work but diminishes level of employee's dissatisfaction. In fact, current role or task is the key to move forward to their next task or promotion and they are required to build their skill according to designation and to build their career as well (Brown, 2004).

\section{STATEMENT OF PROBLEM}

Boredom is one of the most potent problems faced by employees which causes dissatisfaction $\&$ ultimately leads to administrative problems. The top most reason for that employees see tier work as a dead end of their lives they got stressed so that they don't get pride for their work done after completion (Breatty \& Schneier, 1981). The job characteristics model (Hackman \& Oldman, 1976) identifies the conditions necessary for people to become intrinsically motivated and have high work performance. The model suggests that three job dimensions i.e. skill variety, task identity, task significance lead to three critical psychological states (meaningfulness, responsibility, and knowledge of results), which then lead to positive outcomes, such as high work performance. In fact, Choudhary (2016), indicated that if employees don't get pride for their work done after completion it will lead to achieve the target of organization. Thus necessary to check the model of Hackman and Oldman (1976) in the context of employee performance

\section{RESEARCH OBJECTIVES}

1. To evaluate the impact of job enrichment on the employee performance

2. To verify the mediating role of employee motivation in banking sector with the key indicators of job enrichment

3. To know the relationship between task identity and employee performance \& also with employee motivation

4. To know the relationship between task significance and employee performance \& also with employee motivation.

5. To know the relationship between skill variety and employee performance \& also with employee motivation.

\section{SIGNIFICANCE OF RESEARCH}

Performance with productivity decline with the passage of time and roles appropriately is very imperative in elevating the motivation of employees, which is addressed by job enrichment. 
The paper recommends that management of any organization must consider employee's perspective in enriching job description of each position and emphasis should be on enriching the job related concepts in the given society. It would also widen the scope of understanding of the people that constitute the society in the area of enriching banking job. The future researcher will also use this study to expand his or her knowledge of subject matter even as the successful completion of the survey even as inspiration for more tasking in research.

\section{RESEARCH MODEL}

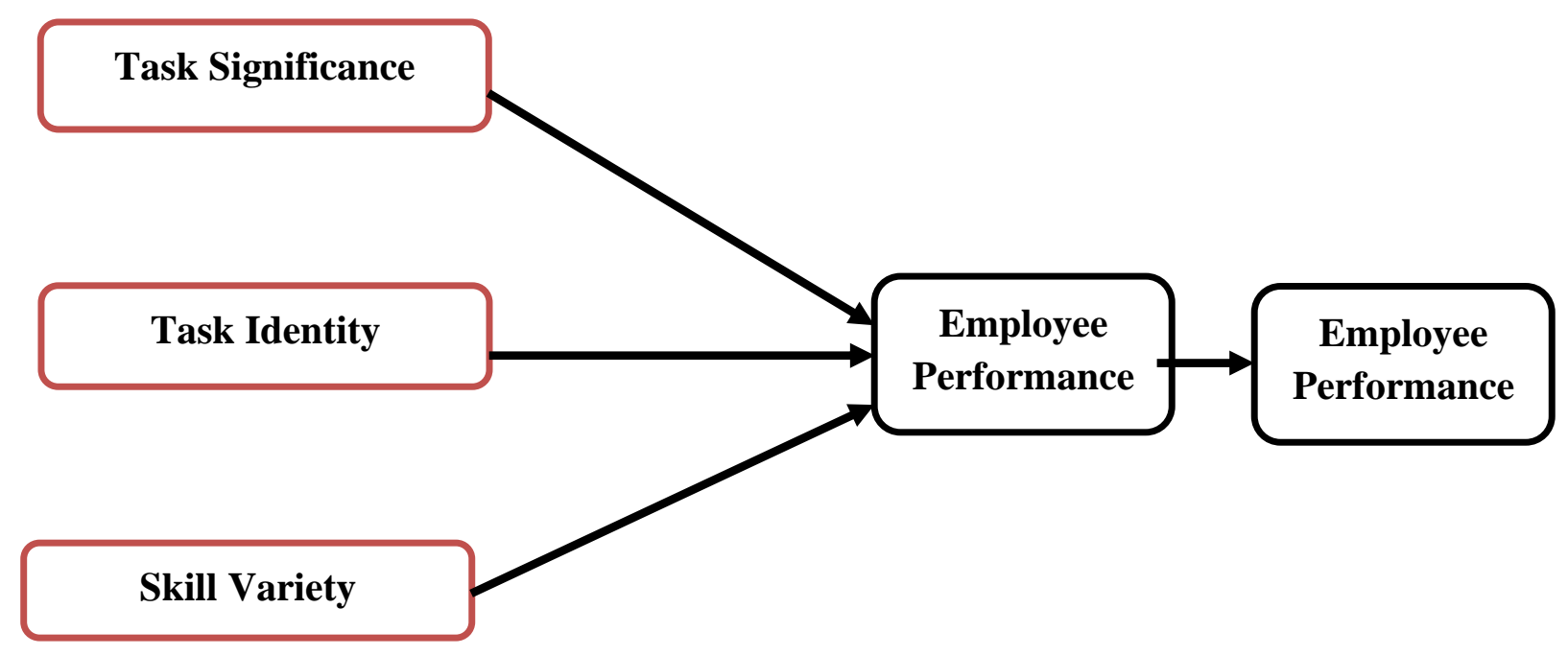

\section{LITERATURE REVIEW}

\section{Task Identity and Employee Performance}

The task identity has a lot of impact on performance of work and employee as well and the out comings from the employee (Humphrey Nargang \& Morgeson, 2007).

Task identity is required when tasks are combined and to complete any project the interest of the employees have to be built by the employers while designing of job (Hackman \& Oldham, 1975). Locke and Edwin (2008) indicated that employees must claim out there identity on completing the task in the amount of work which they rendered.

\section{Task identity \& Motivation}

Employee motivation is explored on the significance in the relationship among the Identity of task and employment (Hackman \& Lawler, 1971). Gatauwa (2014) little mistake of the employer while enriching the job is the lack of knowledge about the identity of a task to the 
employees (Choge ,Chepkiyeng \& Chelimo, 2014). Employer not just have to increase the volume of the employees and motivate them foe the work employer must have to give the quality and the out coming response from the organization in order to boost their selves and make the work more efficient (Freyand \& Osterloh, 2002).

\section{Task significance \& Employee performance}

Task significance is explained as rate at which the integral tasks of the job are significant to the company and have a relevant effect on the job and livelihood of colleagues and those without the organization (Hirschfeld, Schmitt \& Bedeian, 2002). Employees are more motivated to expend effort when they recognize that their actions can benefit others (Karau \& William, 1993). However, most of the research on task significance was conducted before researchers had provided systematic evidence that job performance is influenced by individual differences in employee performance (Barrick, Mount \& Judge, 2001).

\section{Task significance \& motivation}

Chandler (2007), who indicated that a Task identity increase motivation hence improve the performance of employees. On the other hand, the findings on task significance indicate employees performance may not be directly or significantly affected by task significance as explained by the Herzberg two factor theory of Motivation The reason for task significance is to increase employee motivation for the employee that was not enthusiastic about their job. It increased the employees desire to work longer hours, and to do a job well done. Disciplines: Business / The Management / Org Behavior of Employee and Development Of The organization

\section{Skill Variety \& Employee Performance}

Chandler (2007), Employee should feel free while working in an organization as we have to give them a good or excellent working environment so that they can work with more efficiently. We do have to help the employee of a company to enrich their own working skill o perform the tasks perfectly and more efficiently. In the view of Garg \& Rastogi (2006), skill enrichment allows our business to grow with their skills requires the employee to draw from a number of different skills and abilities as well as upon a range of knowledge (Taber \& Taylor, 1990).

It indicates the number of skills that individual employ while performing work. Inherent characteristics of a job including significance of a task and skill variety are usually mostly associated with low rates of absenteeism (Taber \& Taylor, 1990)

\section{Skill Variety \& Motivation}

Variety of skills offer increment in the business profile of an organization it includes use of a number of different skills and talents of the person (Hackman \& Oldham, 1976). When we engage a person in any task the employee should be aware of that what he she is doing. Incentive and other curricular activities make the employee fresh and happy which will increase their performance level because they tap and test the intellective or motor skills of the people 
(Hackman \& Oldham, 1976). In fact, Ambrose et al (2013) uses the citation of Campion et al (2005), and Perry et al., (2006) performance of an employee should be determined by their skills and tasks. The Positive and strong relationship exist between the extent of a firm's adoption of high involvement HRM strategies including skill variety.

\section{RESEAERCH METHODOLOGY}

\section{Research Design}

The philosophy behind this study is epistemology and the stance is post-positivism as the study is trying to uncover ideas which will aid to knowledge building through quantitative approach (Saunders et al., 2009). The purpose of research is correlational and study setting was noncontrived as the study was conducted with the ease of respondents but the framework was developed through merging prior studies (Sekaran \& Bougie, 2016). The research strategy was survey and the time horizon was cross-sectional as this study was based on data collection through closed ended questionnaire which are analyzed once through SMART-PLS (Saunders et al., 2009).

\section{Sampling Design}

The study was conducted in the banking sector of Pakistan in order to gauge the relationship between job enrichment and employee performance. Banking sector is purposely selected for this study as the sector is majorly focused on profit generation which force enormous burden on employees which ultimately resulted in decrease of motivation.

Especially in private sector banks where retention of employees is a real challenge for the managers (Rashidi \& Rahman, 2013). Study uses quota sampling approach as the strategy of job enrichment is from employer and therefore HR managers having experience of dealing issues in banking sector are in the research population. The sample size is of 100 respondents which cover HR managers from almost all the leading banks operating in Pakistan.

\section{STATSITICAL TESTING}

\section{R Square:}

\begin{tabular}{lcc}
\hline & R Square & R Square Adjusted \\
\hline Employee Performance & 0.715 & 0.71 \\
Employee Motivation & 0.734 & 0.731 \\
\hline
\end{tabular}


Table 1: Quality Criteria (Predictive Accuracy)

\begin{tabular}{lllll}
\hline & $\begin{array}{l}\text { Cronbach's } \\
\text { Alpha }\end{array}$ & rho_A & $\begin{array}{l}\text { Composite } \\
\text { Reliability }\end{array}$ & AVE \\
\hline $\begin{array}{l}\text { Employee } \\
\text { Motivation }\end{array}$ & 0.84 & 0.841 & 0.893 & 0.675 \\
$\begin{array}{l}\text { Employee } \\
\text { Performance }\end{array}$ & 0.79 & 0.801 & 0.864 & 0.615 \\
Skill Variety & 0.813 & 0.832 & 0.889 & 0.728 \\
$\begin{array}{l}\text { Task Identity } \\
\text { Task }\end{array}$ & 0.808 & 0.812 & 0.874 & 0.635 \\
Significance & 0.842 & 0.85 & 0.905 & 0.76 \\
\hline
\end{tabular}

Table 2: Construct Reliability and Validity

\begin{tabular}{lrrrrr}
\hline EM & EP & $\mathrm{SV}_{-}$ & TI_ & TS & EM \\
\hline EM & $\mathbf{0 . 8 2 2}$ & & & & \\
EP & 0.769 & $\mathbf{0 . 7 8 4}$ & & & \\
SV_ & 0.824 & 0.781 & $\mathbf{0 . 8 5 3}$ & & \\
TI_ & 0.734 & 0.74 & 0.687 & $\mathbf{0 . 7 9 7}$ & \\
TS & 0.729 & 0.747 & 0.788 & 0.697 & $\mathbf{0 . 8 7 2}$ \\
\hline
\end{tabular}

Table 3: Discriminant Validity Fornell-Larcker Criterion

\begin{tabular}{|c|c|c|c|c|c|}
\hline & EM & EP & $\mathrm{SV}_{-}$ & TI_ & TS \\
\hline EM & 0.543 & & & & \\
\hline EP & 0.484 & 0.464 & & & \\
\hline $\mathrm{SV}_{-}$ & 0.385 & 0.321 & 0.337 & & \\
\hline TI_ & 0.361 & 0.303 & 0.348 & 0.345 & \\
\hline TS & & & & & \\
\hline
\end{tabular}




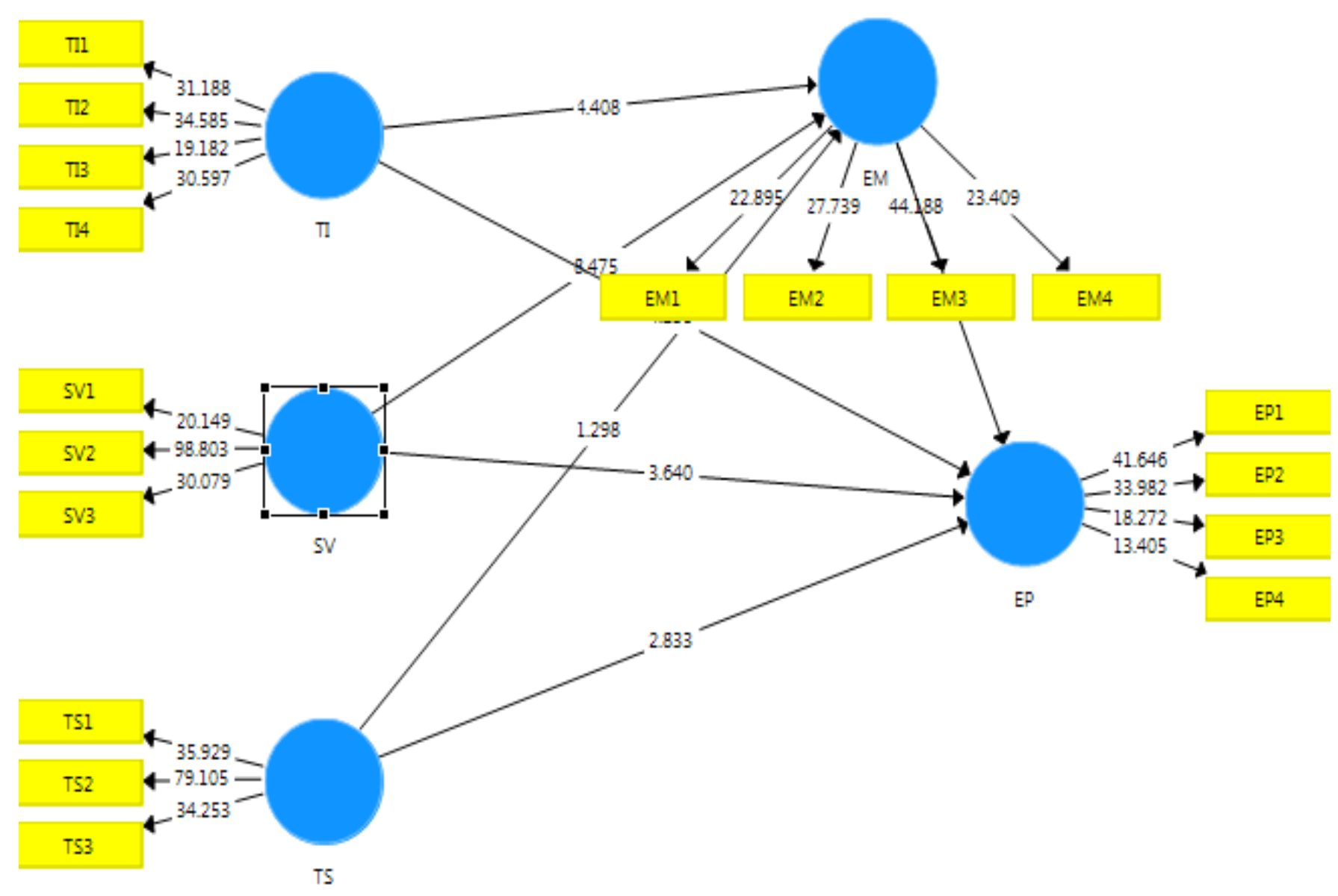

Figure 1: T-Statistics and Path Coefficient for the effect of Job Enrichment on Employee Performance

Table 4: Path Coefficients

\begin{tabular}{|l|r|r|r|r|r|}
\hline & \multicolumn{1}{|l|}{$\begin{array}{l}\text { Original } \\
\text { Sample (O) }\end{array}$} & $\begin{array}{l}\text { Sample } \\
\text { Mean (M) }\end{array}$ & $\begin{array}{l}\text { Standard } \\
\text { Deviation } \\
\text { (STDEV) }\end{array}$ & $\begin{array}{l}\text { T Statistics } \\
(\mid \mathbf{O} / \text { STDE } \\
\text { V|) }\end{array}$ & P Values \\
\hline EM -> EP & 0.206 & 0.206 & 0.072 & 2.844 & 0.005 \\
\hline SV_-> EM & 0.552 & 0.565 & 0.065 & 8.475 & 0.003 \\
\hline SV_-> EP & 0.277 & 0.28 & 0.076 & 3.64 & 0.004 \\
\hline TI_-> EM & 0.291 & 0.283 & 0.066 & 4.408 & 0.002 \\
\hline TI_-> EP & 0.262 & 0.269 & 0.062 & 4.238 & 0.003 \\
\hline TS -> EM & 0.09 & 0.087 & 0.07 & 1.298 & 0.195 \\
\hline TS -> EP & 0.196 & 0.187 & 0.069 & 2.833 & 0.005 \\
\hline
\end{tabular}

Table 4 highlighted the result on the mediating variable (EM) and the dependent variable (EP). As per the table Skill Varity (SV) has significant impact on dependent variable (EP) thus 
researchers rejects the null hypothesis (t-value $<2$, P Value $>0.05$ ). SV also have a significant impact with mediation $(\mathrm{EM})$ because of reject the null hypothesis $(\mathrm{T}$ value $>2$, $\mathrm{P}$ value $<0.05$ ) so the Partial mediation take place has been indulged in the process. Moreover, (TI) also has a significant impact on EP (t-value $>2$, p-value $<0.05$ ), similarly TI (t-value $>2, \mathrm{P}$-value $<0.05$ ). However, TS does not have significant impact EM (t-value2<, p-value >0.05).

\section{CONCLUSION}

On the bases of statistical testing almost all the relationships attained satisfactory results except the relationship of task significance and employee motivation. This might be found appropriate as task significance fosters meaningfulness which is a mediator between task significance and organizational commitment (Allan, Duffy \& Collisson, 2018). Moreover, all the other relations found to be effective and provides positive impact on the level of motivation as well as job performance of employees.

\section{RECOMMENDATIONS AND AREA FOR FUTURE RESEARCH}

After detailed analysis and evaluation of results it has ben recommended that non-financial compensation like job enrichment are beneficial for employee motivation as well as performance.

However, further research may be done in public sector banks just to optimize the level of understanding similarly the study might be conducted in micro finance banking. However these indication and enhancement might only aids in knowledge with in one particular field i.e. banking hence cross industry analysis might be further fruitful for the research and knowledge creation. Similarly inducing study with the moderator like gender may also supplement learning and knowledge. 


\section{REFERENCES}

Allan, B. A., Duffy, R. D., \& Collisson, B. (2018). Task significance and performance: Meaningfulness as a mediator. Journal of Career Assessment, 26(1), 172-182.

Barrick,Mount \& Judge. (2001). Personality and performance at the beginning of the new millennium: What do we know and where do we go next? International Journal of Selection and Assessment, 9, 9-30.

Behson, Eddy \& Lorenzet. (2000). The importance of the criticalpsychological states in the job characteristics model A meta-analytic andstructural equations modeling examination. Current Research in SocialPsychology, 5(12), 170-189.

Bratton \& Hower. (2007,2008). Job Enrichment and its Impact on Emloyee Performance. Asia pacific Journal of Research, 1(15), 8.

Bratton . (2007). Work \& Organization Behavior. Paul Grave MacMillan., 1(15), 8.

Breatty \& Schneier. (1981). Personnel Administration and Experiential skill building approach. Addison. Wesley Publishing Company Inc.

Brown, M. (2012). Responses to work intensification: does generation matter?. The International Journal of Human Resource Management, 23(17), 3578-3595.

Brown, R. (2004). Job Enrichment and Its Impact on Employee Performance in IT Industry. Asia Pacific Journal, 1(15).

Choge ,Chepkiyeng \& Chelimo. (2014). Effects of Task Identity on Employee Motivation:The International Institute for Science, Technology and Education (IISTE). European Journal of Business and Management., 6(33).

Dost \& Khan. (2012). Job Enrichment causes high level of emloyee commitment during the performance of their duties. Arabian Journal of Bussiness Management Review, 1(9), 95-104. 
Dost, M. K. B., \& Khan, H. J. (2012). Job enrichment causes high level of employee commitment during the performance of their duties: A behavioral study. Arabian Journal of Business and Management Review (Oman Chapter), 1(10), 95.

Freyand \& Osterloh. (2002). Effects of Task Identity on Employee Motivation: A Survey of Eldoret Polytechnic, Kenya. European Journal of Business and Management, 6(33), 2222-1905.

Garg, P., \& Rastogi, R. (2006). New model of job design: motivating employees' performance. Journal of management Development. 25(6),. 572 - 587.

Gatauwa. (2014). A survey of Private Equity Investments in Kenya,. European Journal of Business and Management, 3(6).

Hackman \& Lawler. (1971). Employee reactions to job characteristics. Journal of Applied Psychology, 259-286.

Hackman \& Oldham. (1975). Development of the job diagnostic survey. Journal of Applied Psychology, 159-170.

Hackman \& Oldham. (1976). Job Characteristics and Employee Performance in Private Equity Firms in Kenya. IOSR Journal of Business and Management (IOSR-JBM), 20(1), 6070.

Hair jr, J. F., Hult, G. T., Ringle, C., \& Sarstedt -, M. (2014). A Primer on Partial Least Squares Structural Equation Modeling (PLS-SEM). sage.

Hair, J., Black, W., Babin, B., \& Anderson, R. (2010). Multivariate Data Analysis. PrenticeHall.

Henseler, J., Ringle, C., \& Sarstedt, M. (2015). A new criterion for assessing discriminant validity in variance-based structural equation modeling. 
Herzberg. (1968). One More Time: How Do You Motivate Employees? Harvard Business Review, 46, 53- 62.

Hirschfeld,Schmitt \& Bedeian. (2002). Job-content perceptions, performance.

Humphrey Nargang \& Morgeson. (2007). Integrating, motivational, social, and contextual work design features: A meta-analytic summary and theoretical extension of the work design literature. Journal of Applied Psychology, 5(92), 1332-1356.

Kamal,chris,Patterson,Robinso,Stride,Wall \& Wood. (2008). The impact of human resource and operationalmanagement practices on company productivity: a longitudinal study. Personnel Psychology.

Karau \& William. (1993). Social loafing: A meta-analytic review and theoretical integration. Journal of Personality and Social(65), 681-706.

Kotila. (2001). Job Enrichment and Its Impact On Emloyee Performance. Asia Pacific Journal Of Research, 1(15).

Larcker, D. F., \& Fornell, C. (1981). Evaluating Structural Equation Models with Unobservable Variables and Measurement Error. Journal of Marketing Research, 39-50.

Locke \& Edwin. (2008). Goal setting \& task performance. Psychological Bulleti, 125-152.

Mione, P. (2004). Job enrichment. Online Paper.

Mohsan, F., Nawaz, M. M., Khan, M. S., Shaukat, Z., \& Aslam, N. (2011). Impact of customer satisfaction on customer loyalty and intentions to switch: Evidence from banking sector of Pakistan. International journal of business and social science, 2(16).

Raza, M. A., \& Nawaz, M. M. (2011). Impact of job enrichment on employees' job satisfaction, motivation and organizational commitment: evidence from public sector of Pakistan. European Journal of Social Sciences, 23(2), 220-226. 
Rentch \& Steel. (2004). Testing the durability of job characteristics as predictors of absenteeism over a six-year period. Personnel Psychology,. Journal of Business and Psychology(16), 553-564.

Siu, Lu, Brough,Bakker. (2010). Role Resourceand work family enrichment : The role of. Journal of Vocational Behavior, 3(77), 470-480.

Slocum \& Sims. (2000). A Typology for Integrating Technology, Organization, and Job Design. Human Relations , 193 -212.

Slocum Jr, J. W., \& Sims Jr, H. P. (1980). A typology for integrating technology, organization, and job design. Human Relations, 33(3), 193-212.

Taber \& Taylor. (1990). A review and evaluation of the psychometric properties of the Job Diagnostic Survey. Personnel Psychology(43), 467-497.

Wall and Leach. (2002). Job Enrichment and its Imact on Employee Performance. Asia Pacific Journal, 1(15), 50-78. 